A N N A L E S

UNIVERSITATIS M A R I A E C URIE-SKŁODOW S K A

LUBLIN - POLONIA

VOL. XXXIII, 2

SECTIO J

2020

Uniwersytet Pedagogiczny im. Komisji Edukacji Narodowej w Krakowie. Wydział Pedagogiczny

\title{
JOANNA RUCZAJ
}

ORCID: 0000-0002-5723-9130

joanna.ruczaj@up.krakow.pl

\section{Doświadczenie żałoby po samobójczej śmierci bliskiego - zagrożenia i metody wspierania pozostawionych}

The Experience of Mourning after the Suicidal Death of a Loved One -

Risk Factors and Ways to Support Suicide Survivors

Propozycja cytowania: Ruczaj, J. (2020). Doświadczenie żałoby po samobójczej śmierci bliskiego zagrożenia i metody wspierania pozostawionych. Annales Universitatis Mariae Curie-Sklodowska. Sectio J, Paedagogia-Psychologia, 33(2), 285-300. DOI: http://dx.doi.org/10.17951/j.2020.33.2.285-300.

\section{STRESZCZENIE}

Celem artykułu było wskazanie specyfiki przeżywania samobójczej śmierci bliskiego w rzeczywistości społecznej, która jest nieprzychylna doświadczaniu tej utraty. W tekście poruszono problem tabuizacji zjawiska samobójstwa oraz stygmatyzacji społecznej samobójców i ich rodzin. Przegląd doniesień z badań poświęconych poznaniu tego zagadnienia wsparto przytoczonymi świadectwami osób przeżywających żałobę po samobójczej śmierci bliskiego. Rozważono różnice przeżywania żałoby po śmierci samobójczej i po śmierci z przyczyn naturalnych. Przedmiotem refleksji są zwłaszcza te aspekty doświadczenia bliskich samobójców, które nie odpowiadają społecznie aprobowanym wzorcom doświadczania żałoby (m.in. brak aprobaty społecznej dla wyrażania emocji gniewu i doświadczenia ulgi w kontekście przeżywania śmierci bliskiego). Na podstawie analizy przedstawionych materiałów wskazano potencjalne zagrożenia, które mogą dotykać tej grupy żałobników. W tym celu omówiono badania poświęcone analizie ryzyka wystąpienia zaburzeń psychicznych pośród bliskich samobójców. W kontekście poczynionych w artykule obserwacji rozważono efektywność terapii Complicated Grief Treatment dedykowanej pracy z tą grupą klientów.

Słowa kluczowe: samobójstwo; żałoba; bliscy samobójców; terapia

\section{WPROWADZENIE}

Rozważając społeczne znaczenie wzrostu liczby samobójstw w Polsce i na świecie (WHO, 2014; dane KGP i GUS z lat 1999-2018), należy dostrzec, 
że doświadczenie samobójczej śmierci nie dotyczy wyłącznie osoby, która decyduje się odebrać sobie życie. Jedno samobójstwo wpływa średnio na 5-10 osób z jej najbliższego otoczenia (Gmitrowicz, 2010), które konfrontując się z doświadczoną stratą, muszą przejść przez trudny proces żałoby. Odnosząc się do średniej liczby samobójstw w Polsce (dane KGP i GUS z lat 1999-2018), należy wskazać, że co roku w naszym kraju żałoba po samobójstwie może dotykać nawet 60 tys. osób. Trzeba zauważyć, że efektywna prewencja samobójstw w tej grupie szczególnego ryzyka wystąpienia skłonności samobójczych wymaga świadczenia kompleksowej opieki dla bliskich suicydenta, co dotyczy praktyk udzielania profesjonalnego wsparcia (tj. podejmowania działań postwencyjnych) podczas przechodzenia przez trudny proces żałoby po samobójstwie.

Celem zamieszczonego w artykule przeglądu doniesień z badań jest przybliżenie doświadczenia osób przeżywających samobójczą śmierć bliskiego. Podczas dokonywania opisu tego doświadczenia wykorzystano również świadectwa tego przeżycia (m.in. opublikowane fragmenty wywiadów z bliskimi samobójców). Istotne jest dostrzeżenie specyfiki przeżywania samobójstwa przez bliskich suicydenta, które mogłoby służyć lepszemu rozumieniu tego doświadczenia i wpływać na doskonalenie warsztatu pracy terapeutycznej z tą grupą klientów (tzw. suicide survivors ${ }^{1}$ ).

$\mathrm{W}$ niniejszej pracy $\mathrm{w}$ celu zarysowania znaczenia problemu przedstawiono statystyki wskazujące na skalę występowania zjawiska samobójstw w Polsce i na świecie. Następnie, poprzez odniesienie się do aktualnych badań poświęconych analizie tego problemu, rozważane są wpływ tabuizacji zjawiska samobójczej śmierci w debacie publicznej na sposób przeżywania i dawania wyrazu doświadczania tej utraty przez pozostawionych (suicide survivors) oraz oddziaływanie odnotowywanego doświadczania stygmatyzacji przez bliskich osób, które popełniły samobójstwo, na ich skłonność do dzielenia się swoim doświadczeniem. Poprzez odwołanie się do doniesień z badań i obecnych w literaturze świadectw rozważono też charakterystykę przeżycia osób pozostawionych przez samobójcę. Przedmiotem refleksji są również trudności, które mogą towarzyszyć temu doświadczeniu oraz związane z nimi zagrożenia (m.in. współwystępowanie zaburzeń psychicznych i skłonności samobójczych). W kontekście poczynionych w artykule obserwacji omówiono również efektywność metody terapeutycznej dedykowanej pracy z tą grupą klientów.

1 Osoby przeżywające żałobę po samobójczej śmierci bliskiego określane są w literaturze terminem suicide survivors (por. Mitchell, Kim, Prigerson, Mortimer, 2005; Sakinofksy, 2007; McMenamy, Jordan, Mitchell, 2008; Edmonds, 2016). 


\section{SKALA ZJAWISKA}

Na podstawie danych z raportu WHO z 2014 r. stwierdzono, że średnio co 40 sekund ktoś na świecie odbiera sobie życie. W ciągu roku w wyniku samobójstw umiera na świecie około 800 tys. osób (WHO, 2014-2017). Skalę tego problemu w Polsce oddają dane statystyczne podawane przez Komendę Główną Policji (KGP) oraz Główny Urząd Statystyczny (GUS). Statystyki KGP i GUS z lat 1999-2018 wskazują na tendencję wzrostową liczby samobójstw. W odpowiedzi na zaobserwowany wzrost liczby samobójstw w Polsce w ramach działań Narodowego Programu Ochrony Zdrowia Psychicznego na lata 2012-2015 został sformułowany „Ramowy program zapobiegania samobójstwom w Polsce" (Brodniak, 2012). Ewaluacja skuteczności podjętych działań, oparta na analizie statystyk liczby samobójstw w latach 2011-2018, wskazuje, że program jednak nie przyniósł oczekiwanych rezultatów. Każdego roku żałoba po samobójstwie może dotyczyć w Polsce nawet 60 tys. osób.

Doświadczenie bliskich osób, które zdecydowały się odebrać sobie życie, staje się obecnie przedmiotem pogłębionych analiz (zob. m.in. liczne prace Katherine Shear z Columbia University oraz Larsa Mehluma z University of Oslo), efektem których jest powstawanie i testowanie skuteczności różnych metod pracy terapeutycznej z tą grupą klientów (m.in. Shear, 2010; Cohen, Mannarino, Deblinger, 2011; Edmonds, 2016). Biorąc pod uwagę skalę oraz dynamikę rozwoju zjawiska samobójstw w naszym kraju, może zastanawiać obserwowana w polskiej literaturze nieznaczna liczba analiz poświęconych opisaniu tego przeżycia (m.in. Gmitrowicz, 2010; Więdłocha, 2019). Przyczyną zaistniałych braków może być trudność przeprowadzenia badania tej grupy osób, ponieważ ze względu na wciąż silną tabuizację tematu samobójczej śmierci oraz doświadczaną stygmatyzację ze strony najbliższego otoczenia nie są one skłonne dzielić się swoim przeżyciem utraty (Jordan, 2001; McMenmy i in., 2008).

\section{TABUIZACJA ZJAWISKA SAMOBÓJSTWA I SPOŁECZNA STYGMATYZACJA POZOSTAWIONYCH BLISKICH OSÓB, KTÓRE ODEBRAŁY SOBIE ŻYCIE}

Przedmiotem wielu badań jest przez wieki ugruntowane w kulturze tabu narosłe wokół tematu samobójczej śmierci (zob. m.in. Ringel, 1987; Jordan, 2001; Lukas, Seiden, 2007). Milczenie otoczenia na temat samobójstwa często traktowane jest jako wyraz potępienia tego czynu i społecznego wykluczenia osób popełniających samobójstwo, które dotyka także ich pozostawionych bliskich (Lukas, Seiden, 2007, s. 29).

$\mathrm{W}$ badaniach poświęconych analizie występowania tabuizacji zjawiska samobójczej śmierci (Thornton, Whittemore, Robertson, 1989) stwierdzono społeczne unikanie podejmowania rozmów o samobójstwie z żałobnikami. Interpretując wyniki, badacze podkreślali zwłaszcza niechęć do rozmowy o samobójstwie 
z przeżywającymi żałobę kobietami, które postrzegane są jako przejawiające większe trudności w procesie readaptacji do życia po doświadczonej stracie.

Niechęć otoczenia do podejmowania rozmowy o samobójstwie niekiedy motywowana jest obawą, że poruszenie tego tematu będzie wyrazem braku czci dla zmarłego oraz braku szacunku dla jego rodziny (Lukas, Seiden, 2007, s. 104). Jednocześnie badania Toma R. Tylera (1990, za: Nock, 2014) wykazały, że bliscy osób, które popełniły samobójstwo, są częściej postrzegani przez społeczeństwo jako odpowiedzialni za tę śmierć oraz darzeni są mniejszą sympatią (rzadziej obdarzani współczuciem) niż ci, którzy przeżyli śmierć naturalną bliskiej osoby. Odnosząc się do tego kontekstu, czytelny jest niepokój otoczenia, że wezwanie do rozmowy o samobójstwie może zostać przez żałobników niewłaściwie odczytane jako wyraz oskarżenia lub próba wskazania winnego samobójczej śmierci.

Zauważono również, że bliscy zmarłych częściej odczuwają wstyd związany z doświadczeniem samobójczej śmierci bliskiego niż osoby, które przeżyły inny rodzaj śmierci członka rodziny (tj. wypadek, przewlekła choroba) (Grad, Zavasnik, 1999). Badacze sugerują, że doświadczenie to dotyka zwłaszcza rodziców dzieci, które popełniły samobójstwo, gdyż konfrontują się oni z opinią, że nie sprawdzili się w roli opiekunów (Rando, 1985). Doświadczenie wstydu związane jest ze społecznym napiętnowaniem tego rodzaju śmierci oraz tendencją do poszukiwania osób odpowiedzialnych za samobójczy zgon, co istotnie różni samobójczy sposób śmierci od powszechnie podzielanych rodzajów percepcji śmierci z przyczyn naturalnych (Sveen, Walby, 2008). Ten sposób postrzegania samobójstwa prowadzi do sytuacji, w której jedna trzecia ofiar samobójczej śmierci bliskiej osoby żyje w poczuciu społecznego potępienia (Solomon, 1983).

John R. Jordan (2001) podkreśla, że doświadczenie stygmatyzacji szczególnie dotyka sfery emocjonalnej tych żałobników i wywiera wpływ na sposób ich kreowania obrazu siebie. Negatywny sposób postrzegania siebie wpływa na ich sposób nawiązywania interakcji z otoczeniem. Badania wskazują, że bliscy osób, które popełniły samobójstwo, mają trudności w nawiązywaniu relacji społecznych oraz prowadzeniu rozmowy z innymi o doświadczonej śmierci samobójczej (Jordan, 2001; McMenamy i in., 2008). Poczucie bycia napiętnowanym prowadzi następnie do ich wycofywania się z uczestnictwa w życiu społecznym (Sakinofsky, 2007) oraz skłania do ukrywania prawdy o samobójstwie bliskiego (Sveen, Walby, 2007).

Ze względu na opisane społeczne, negatywne przekonania dotyczące środowiska rodzinnego samobójców (spekulacje na temat zaniedbania, zaniechania i patologizacji więzi rodzinnych, które jednak nie znajdują potwierdzenia w badaniach czynników ryzyka występowania skłonności samobójczych; por. Jarosz, 2004) oraz budowane na tej bazie wrogie lub niewspierające postawy społeczne, osoby, które doświadczyły samobójczej śmierci bliskiego, często wzrastają w doświadczanym poczuciu wstydu, napiętnowania i wykluczenia. 
Postępujące wycofanie społeczne oraz brak wsparcia ze strony otoczenia mogą prowadzić do patologizacji procesu żałoby (tzw. CGD) oraz występowania własnych skłonności samobójczych i zachowań autodestrukcyjnych u tej grupy osób (Mitchell i in., 2005). Specyfika przeżywania tej utraty (w porównaniu do doświadczenia śmierci z przyczyn naturalnych) nie jest jednak powodowana wyłącznie przez opisany wykluczający czy stygmatyzujący sposób odbioru społecznego doświadczenia samobójczej śmierci. Efektywne działania terapeutyczne wspierające tę grupę żałobników powinny - poza modelowaniem właściwych, społecznych wzorców zachowania w reakcji na tę utratę - odpowiadać na specjalne potrzeby poznawcze i emocjonalne tej grupy osób (Cohen i in., 2011). Podejmowane w literaturze próby opisu specyfiki doświadczenia samobójczej śmierci bliskiego mają wielokrotnie miejsce poprzez analizy porównawcze raportowanych przeżyć śmierci z przyczyn naturalnych (jako kryzysów o charakterze normatywnym) i samobójczej śmierci bliskiego (Barrett, Scott, 1990; Jordan, 2001).

\section{DOŚWIADCZANIE SAMOBÓJCZEJ ŚMIERCI BLISKIEGO. ANALIZA RÓŻNIC POMIĘDZY SPOSOBEM KONFRONTOWANIA SIĘ BLISKICH ZE ŚMIERCIĄ Z PRZYCZYN NATURALNYCH A PRZEŻYWANIEM SAMOBÓJSTWA}

Badacze podkreślają różnicę pomiędzy sposobem konfrontowania się bliskich ze śmiercią z przyczyn naturalnych a przeżyciem samobójstwa (Barrett, Scott, 1990; Jordan, 2001). Dążąc do zrozumienia specyfiki tego przeżywania, Terence W. Barett i Thomas B. Scott (1990) wyodrębnili cztery rodzaje reakcji, które towarzyszą bliskim samobójców. Pierwszą z nich, która łączy to doświadczenie z przeżywaniem śmierci z przyczyn naturalnych, jest reakcja krótko po stracie. Charakterystyczne jest $\mathrm{w}$ tym przypadku silne pobudzenie emocjonalne i towarzyszące mu objawy fizyczne (płacz, pobudzenie, niepokój i inne symptomy właściwe dla pozostawania w fazie szoku po doświadczeniu utraty) (por. Sanders, 2001). Kolejne wyodrębnione przez tych autorów charakterystyki doświadczenia pozostawionych bliskich dotyczą reakcji w odpowiedzi na ,nienaturalność" i nagłość samobójczej śmierci. Łączą one doświadczenie samobójstwa bliskiego z przeżyciem innych rodzajów tragicznej śmierci (jak m.in. ofiary morderstwa, nieszczęśliwego wypadku, katastrofy naturalnej). Finalnie w swojej koncepcji Barett i Scott odwołują się również do reakcji bliskich samobójców, która odpowiada towarzyszącemu im poczuciu porzucenia i odrzucenia.

Poczucie porzucenia może wiązać się z obserwowanym (silniejszym niż u innych żałobników) doświadczeniem smutku i stresu u bliskich samobójców (m.in. za: Parker, 2014). Ponadto Jordan (2001) zauważa, że istotną różnicą pomiędzy doświadczeniem śmierci naturalnej i śmierci samobójczej jest trudność nadania znaczenia tej stracie, przypisania jej sensu. Uzasadnienia tej trudności być może 
można poszukiwać właśnie w spostrzeżeniu, że w przeciwieństwie do innych rodzajów utraty (jak np. przewlekła choroba, wypadek, morderstwo, śmierć w wyniku katastrofy naturalnej) przeżywający samobójstwo muszą konfrontować się z myślą, że bliski sam odebrał sobie życie, postanawiając ich pozostawić.

Jednak to doświadczenie odrzucenia nie jest przeżywane wyłącznie jako niepokój i przygnębienie związane z odtrąceniem. Niejednokrotnie decyzja samobójcy budzi sprzeciw i poczucie krzywdy u pozostawionych bliskich. Autor pracy Silent Grief, który przeżył samobójstwo matki, opisując kolejne etapy przeżycia samobójczej śmierci, wymienia kolejno szok, zaprzeczenie i gniew (Lukas, Seiden, 2007, s. 37). Analizując cytowane w pracy wypowiedzi bliskich samobójców, można wyróżnić różne znaczenia gniewu w kontekście przeżywania tej utraty:

Amanda (matka uzależnionej dziewczyny): Trudno jest żywić gniew do kogoś, kogo życie było taką udręką i marnym czasem cierpienia. Wierz mi, byłam na nią zła, kiedy żyła i brała te pigułki. (...) Wciąż wiele z tej złości jest we mnie (...).

Anne-Marie (kobieta, której brat odebrał sobie życie): Wrzeszczałam, darłam się przez okno, krzyczałam: Jak mogłeś mi to zrobić? Rzucałam rzeczami. Odczuwałam nienawiść do mojej szwagierki. Intensywną nienawiść. W moim życiu nigdy wcześniej nie doświadczyłam takiego gniewu (...).

Siostrzenica: Kochałam mojego wujka, ale nie mogę zapomnieć mu tego, co zrobił swoim dzieciom, swojej rodzinie. Jestem zła, ponieważ nie potrafię już żywić do niego tych uczuć, które żywiłam wcześniej. Nie potrafię przywoływać dobrych wspomnień o nim ze względu na gniew o to, co zrobił. (Lukas, Seiden, 2007, s. 37-43)

Niekiedy gniew może wiązać się z ambiwalentnymi uczuciami, które łączyły bliskiego z samobójcą przed jego śmiercią. Gniew może być również wyrazem żalu i niezgody na tę śmierć. Ponadto może występować, gdy samobójstwo jest traktowane jako wyraz odwetu czy zemsty na pozostawionych (Harwood, Hawton, Hope, Jacoby, 2002).

W literaturze jest stosunkowo niewiele badań poświęconych doświadczeniu gniewu po samobójstwie bliskiego, czego sugerowaną przyczyną jest brak aprobaty społecznej dla wyrażania tej emocji w kontekście przeżywania żałoby. Ze względu na presję społeczną podobnie nieopisane jest doświadczanie przez bliskich ulgi po śmierci samobójcy (Parker, 2014). Uwzględniając trudności życia z osobą o skłonnościach samobójczych (m.in. w około $80 \%$ przypadków zachowania samobójcze współwystępują z zaburzeniami psychicznymi, a w około 50\% - z uzależnieniami) (por. Jarema, Rebe-Jabłońska, 2016, s. 203), zrozumiała jest ambiwalencja odczuć pozostawionych bliskich. Być może jednak zwłaszcza doświadczenie emocji nieodpowiadających zwykle przeżywaniu żałoby jest szczególnie trudne dla bliskich osób, które odebrały sobie życie i wymaga ono wyboru odpowiednich narzędzi terapeutycznych, umożliwiających przepracowanie tego doświadczenia.

Analizując deklarowane przez osoby bliskie samobójców trudności przeżywania tej śmierci, można dostrzec, że wielu z nich akcentuje potrzebę konfrontowania się z poczuciem winy. W literaturze podkreśla się, że są oni bardziej narażeni 
na uwikłanie w samooskarżenia, częściej dotyka ich poczucie winy oraz przekonanie, że mogli zapobiec tej śmierci (Hawton, Simkin, 2003). Obraz ich doświadczenia uzupełniają doniesienia z badań Johna McIntosha, który zauważył, że pozostawieni bliscy częściej deklarują, że ich rodzina była obwiniana o samobójczą śmierć oraz sami są bardziej skłonni obwiniać innych o przeżywaną stratę (McIntosh, Kelly, 1992). Zaobserwowano, że podejmowanie prób obciążenia innych odpowiedzialnością za traumatyczne wydarzenie może wywierać korzystny wpływ na ich przeżywanie samobójstwa osoby bliskiej, gdyż pozwala zredukować własne poczucie winy, zmniejsza ryzyko rozwoju objawów stresu pourazowego (PTSD) oraz umożliwia zachowanie poczucia własnej wartości (Miller, Porter, 1983). Jednocześnie próby opisania samobójczej śmierci jako zjawiska wykraczającego poza obszar wpływu najbliższych mogą powodować u nich poczucie posiadania braku kontroli nad wydarzeniami w ich życiu. Oddziałuje to na ich doświadczenie poczucia bezpieczeństwa związane $\mathrm{z}$ wiarą $\mathrm{w}$ przewidywalność uporządkowanego świata, w którym tylko niekiedy mają miejsce negatywne zdarzenia (Janoff-Bulman, 1992).

W przytoczonych badaniach Dale'a T. Millera i Carola A. Portera (1983) zaznaczono ważny temat ryzyka wystąpienia zaburzeń psychicznych wśród bliskich samobójców. Jak twierdzi Isaac Sakinofsky (2007), ryzyko pojawienia się objawów depresji lub PTSD u osób, które przeżywają samobójczą śmierć, jest wyższe niż w przypadku osób, które doświadczyły innego rodzaju utraty. Doświadczanie PTSD intensyfikuje proces przeżywania żałoby (Kaltman, Bonanno, 2003), co utrudnia i niekiedy wydłuża proces akceptacji śmierci bliskiej osoby, a także może prowadzić do jego patologizacji (Complicated Grief Disorder, Prolonged Grief Disorder, Persistent Complex Bereavement Disorder).

\section{KOMPLIKACJE W PROCESIE PRZEŻYWANIA ŻAŁOBY PO SAMOBÓJCZEJ ŚMIERCI BLISKIEGO}

Na podstawie doniesień z wieloletnich badań prowadzonych z żałobnikami badacze wyodrębnili typowy i atypowy sposób przeżywania śmierci (zob. m.in. prace Ericha Lindemanna, 1944, za: Ostrowska, 1997). W piątej edycji indeksu diagnostycznego DSM została zaproponowana jednostka diagnostyczna (Complicated Grief Disoroder - CGD), której kryteria diagnostyczne mają wspomagać specjalistów w rozpoznawaniu patologicznych form przeżywania żałoby. Przedmiotem dyskusji jest zasadność stwierdzania występowania zaburzeń na podstawie odbiegającego od wyznaczonej normy, czasu trwania i intensywności przeżywania śmierci. Co istotne, opisy tego doświadczenia na pewno pozwalają zwrócić uwagę na specyfikę tego przeżywania.

Rozważając żałobę po samobójstwie w kontekście wspomnianych atypowych wzorców przeżywania śmierci, należy pamiętać, że wiele objawów żałoby po śmierci bliskiego jest naturalną odpowiedzią na doznaną stratę. Zazwyczaj 
krótko po śmierci bliskiego raportowane są: poczucie braku, tęsknota, smutek, potrzeba ponownego zobaczenia zmarłego, utrata zainteresowania uczestniczeniem w dotychczasowych aktywnościach (Zhang, El-Jawahri, Prigerson, 2006). Po upływie około sześciu miesięcy (Zhang i in., 2006) osoba najczęściej „,godzi się" ze stratą, powraca do zawieszonych aktywności i jest przygotowana do kontynuowania swojego życia bez obecności zmarłego bliskiego (Stroebe, Stroebe, 1987). Jednocześnie psychologowie zwracają uwagę, że odmienny przebieg żałoby (który kwalifikowałby ją do rozpoznania CGD) obserwują nawet u 10-15\% swoich pacjentów (Bonanno, Kaltman, 2001).

Odnosząc się do zaproponowanych ram opisu doświadczenia żałoby (m.in. DSM-V), można dostrzec, w jaki sposób różni się to doświadczenie w przypadku samobójczej śmierci. Badacze wyodrębniają trzy rodzaje reakcji poznawczych, specyficznych dla odpowiedzi na tę stratę, które powodują podtrzymanie żałoby i wzrost jej intensywności (Boelen, 2006). Charakterystyki te niejednokrotnie towarzyszą przeżyciu bliskich samobójców, którzy: 1) nie mogąc pogodzić się ze stratą, włączają ją do narracji swojego życia (samobójcza śmierć bliskiego stanowi dla nich punkt odniesienia dla tworzonych opisów swojego doświadczenia); 2) nie akceptują swojego doświadczenia utraty (sposobu, w jaki przeżywają tę utratę, np. To nie jest normalne, że tak to przeżywam), podczas gdy doznana strata istotnie modyfikuje ich sposób postrzegania swojego życia i otaczającego świata (np. poprzez konsekwentne negowanie możliwości czerpania przyjemności z życia po samobójstwie bliskiego: Życie już nigdy nie będzie przyjemne); 3) unikają uczestniczenia w aktywnościach, które dawniej sprawiały im przyjemność oraz przejawiają skłonności do inicjowania celowych ruminacji, aby odroczyć doświadczenie akceptacji straty.

Opisany sposób przechodzenia przez proces żałoby może wpływać na wzrost intensywności przeżywania żałoby oraz wydłużenie czasu trwania tego procesu, co odpowiada charakterystykom jednostki diagnostycznej Complicated Grief Disorder. Diagnoza CGD u osób bliskich samobójców jest szczególnie niebezpieczna, gdyż stwierdzono, że to zaburzenie powoduje dziesięciokrotny wzrost prawdopodobieństwa wystąpienia myśli samobójczych w tej grupie (Mitchell i in., 2005). Uwzględniając dane wskazujące, że co trzecia osoba z myślami samobójczymi zaczyna planować samobójstwo (Gmitrowicz, Rosa, 2007), podejmowanie prób opisu doświadczenia osób przeżywających samobójczą śmierć bliskiego ma na celu zarówno pozyskanie danych służących przyszłym projektom wdrażania działań postwencyjnych pośród bliskich suicydentów (doskonalenie technik wspierania i pracy terapeutycznej z tą grupą klientów), jak i przeciwdziałanie występowaniu ich własnych zachowań samobójczych (prewencja samobójstw w tej grupie osób).

Zarysowana powyżej, oparta na analizie świadectw oraz przeglądzie doniesień z badań, charakterystyka doświadczenia żałoby po samobójczej śmierci bliskiego miała na celu zaznaczenie specjalnych potrzeb tej grupy osób. Analiza 
specyfiki przeżywania tej utraty skłania badaczy do poszukiwania nowych form pracy terapeutycznej z osobami bliskimi samobójców.

\section{DZIAŁANIA POSTWENCYJNE W GRUPIE OSÓB PRZEŻYWAJĄCYCH ŻAŁOBĘ PO SAMOBÓJCZEJ ŚMIERCI BLISKIEGO}

Złożoność doświadczenia żałoby po samobójczej śmierci bliskiego można dostrzec, analizując świadectwa pozostawionych bliskich samobójców (Lukas, Seiden, 2007) oraz wypowiedzi lekarzy i terapeutów, którzy podkreślają szczególne wyzwania pracy z tą grupą klientów (m.in. Rycoft, 2004; Roston, 2017).

Wskazane charakterystyki przeżywania żałoby po samobójstwie akcentują potrzebę zastosowania metod pracy terapeutycznej, które nie tylko umożliwiają udzielanie wsparcia pozostawionym (suicide survivors) w procesie akceptacji ich utraty i readaptacji do życia po samobójstwie (tj. w adaptacyjnym przejściu przez poszczególne stadia przeżycia żałoby) (por. Sanders, 2001; Kubler-Ross, 2002), lecz także pozwalają ograniczyć negatywny wpływ objawów zaburzeń psychicznych najczęściej występujących w tej grupie klientów, tj. depresji i PTSD (Sakinofsky, 2007). Badacze podkreślają, że rozwój zaburzeń psychicznych u pozostawionych bliskich istotnie wpływa na sposób ich przechodzenia przez proces żałoby, co może prowadzić do występowania nieadaptacyjnych form jej przeżywania (m.in. Complicated Grief Disorder, Prolonged Grief Disorder, Persistent Complex Bereavement Disorder).

Autorzy (Cohen i in., 2011) dążący do dostosowania modelu pracy terapeutycznej do tej grupy klientów akcentują znaczenie traktowania doświadczenia samobójczej śmierci bliskiego jako doświadczenia kryzysu nienormatywnego, posiadającego cechy wydarzenia traumatycznego i mogącego prowadzić do wystąpienia urazów psychicznych o charakterze przewlekłym (Shear, 2010). W okresie upływającym od samobójstwa bliskiego można dostrzec u pozostawionych (suicide survivors) rozwój behawioralnych, poznawczych i afektywnych objawów pourazowych (por. Cohen i in., 2011, s. 6-13).

Terapeuci zwracają uwagę, że u osób dotkniętych żałobą po samobójstwie mogą być obserwowane wzmożony lęk, gniew, obniżony afekt (skłonności depresyjne) oraz ogólna dysregulacja emocji (por. Lukas, Seiden, 2007, s. 37-43; Cohen i in., 2011, s. 6-13). Wykształca się również skłonność do unikania sytuacji, osób i miejsc, które są przez tę osobę wiązane z doświadczeniem traumatycznego wydarzenia. Tendencja do unikania potencjalnie zagrażających bodźców ma zasadniczo adaptacyjny charakter, lecz ich nadmierna generalizacja może prowadzić do postępującego wycofania społecznego i izolacji tej grupy żałobników (por. Cohen i in., 2011, s. 9-10). Skłonność do unikania współwystępuje z utrwalaniem się u nich nieracjonalnych przekonań, takich jak m.in. intensywne, nieadekwatne poczucie winy i odpowiedzialności za tę śmierć lub uogólnione przekona- 
nie o nieprzewidywalnym i zagrażającym charakterze egzystencji w świecie (por. Cohen i in., 2011, s. 12-13).

Proponowany w literaturze model pracy terapeutycznej z tą grupą klientów został skonstruowany w odniesieniu do odnotowanych objawów w celu korygowania emocjonalnych i poznawczych błędów przetwarzania śmierci samobójczej. Zasadniczym dążeniem podejmowanych działań terapeutycznych jest integracja doświadczenia żałoby z ,ja” pacjenta (por. Cohen i in., 2011, s. 17).

Odnosząc się do poczynionych w artykule obserwacji, do omówienia wybrano model wykorzystywany w pracy terapeutycznej z osobami przeżywającymi żałobę po samobójczej śmierci bliskiego. Terapia Complicated Grief Treatment (CGT) oparta jest na wynikach wieloletnich badań Katherine Shear (Columbia University). Metoda zostanie przybliżona poprzez przedstawienie jej podstawowych założeń teoretycznych, a następnie wskazanie poszczególnych etapów pracy terapeutycznej wyodrębnionych $\mathrm{w}$ ramach tego podejścia.

\section{COMPLICATED GRIEF TREATMENT (CGT)}

Omawiane podejście do terapii żałoby oparte jest na opisach tego doświadczenia konstruowanych $\mathrm{w}$ odniesieniu do ram teoretycznych modelu teorii przywiązania (Bowlby, 1980). Odwołując się do koncepcji Johna Bowlby'ego, M. Katherine Shear (2010) zauważa, że za tworzenie relacji przywiązania odpowiada wrodzony instynkt. Podczas nawiązywania więzi z bliskimi tworzone są indywidualne narracje na ich temat oraz są gromadzone fakty, które umożliwiają adekwatny opis ich zachowania. Zebrane dane stanowią podstawę do formułowania reguł, które umożliwiają rozumienie i przewidywanie sposobu działania bliskich, a także budowanie wobec nich oczekiwań (Shear, 2010). Sformułowane reguły wywodzą się z powtarzających się doświadczeń, dlatego pojawia się znaczny opór w odpowiedzi na przeżycie (np. czyn samobójczy), które nie wpisuje się w przyjęte, znane schematy opisu zachowania bliskich. Doświadczenie traumy może być opisywane jako przeżycie rozbieżności pomiędzy aktualnym wydarzeniem (traumatycznym doświadczeniem) a zbiorem tych zinternalizowanych zasad (Janoff-Bulman, 1992). Shear (2010) zauważa, że samobójcza śmierć bliskiej osoby spełnia kryteria tak definiowanego doświadczenia traumy, dlatego wymaga wykorzystania specjalnych technik w procesie terapeutycznym.

Szczególna adekwatność wykorzystania metody CGT w pracy z osobami przeżywającymi żałobę po samobójczej śmierci bliskiego została potwierdzona w badaniach prowadzonych przez ośrodek prewencji samobójstw funkcjonujący przy Uniwersytecie w Oslo (m.in. badania Larsa Mehluma). W przypadku śmierci bliskiej osoby (zwłaszcza nagłego i tragicznego zgonu) względnie szybko (po przejściu przez fazę szoku, wyparcia i zaprzeczenia) (por. Kubler-Ross, 2002) przetwarzane są fakty odnośnie do tego wydarzenia, a więc modyfikacji podlega- 
ją stworzone narracje na temat bliskiego (tzn. rodzina przyjmuje informację na temat zgonu, rozumie nieodwracalność tego wydarzenia, przygotowuje się do pochówku ciała). Badacze podkreślają jednak znaczną trudność modyfikacji zinternalizowanych zasad określających ich dotychczasową relację ze zmarłym. Trudność przyswojenia nowych reguł w relacji z bliskim (przede wszystkim akceptacji braku jego obecności) ogranicza możliwość efektywnej dezaktywacji powstałego systemu przywiązania, co odpowiada za możliwość akceptacji doświadczonej utraty i readaptacji do życia po samobójstwie bliskiego.

Zgodnie z tym ujęciem adaptacyjne przeżycie żałoby można opisać jako proces nieustannego konfrontowania się z doświadczeniem utraty (Parkes, 1996, za: Shear, 2010). W trakcie terapii celowe przywoływanie narracji o śmierci bliskiego przyczynia się do konstruowania nowego modelu relacji ze zmarłym, który zawiera informacje o ostateczności straty i jej konsekwencjach dla tego związku. Akceptacja faktu samobójczej śmierci umożliwia bliskim rewizję ich celów i planów życiowych, które będą realizowane już w świecie bez obecności zmarłej osoby.

Początkowo proces konfrontowania się z doświadczeniem śmierci bliskiego jest silnie naładowany emocjonalnie $\mathrm{i}$ jest wymagający poznawczo, co znajduje odzwierciedlenie w zachowaniu żałobnika oraz negatywnie wpływa na jego relacje społeczne (m.in. skłonność do unikania bodźców kojarzonych $\mathrm{z}$ doświadczeniem traumy i związane $\mathrm{z}$ tym postępujące wycofanie społeczne). Proces terapeutyczny wymaga korekcji myśli i przekonań, które utrudniają akceptację utraty (m.in. nieadekwatne, intensywne poczucie winy, poczucie krzywdy i wstydu). Podejmowane działania wspomagające funkcjonowanie bliskich zmarłego uwzględniają zarówno strategie ukierunkowane na wspieranie procesu akceptacji tej śmierci, jak i odbudowę bliskich relacji tworzonych przez osobę pogrążoną w żałobie. Działania podejmowane w ramach modelu terapii CGT zwykle obejmują 16 spotkań, które odbywają się w ciągu czterech miesięcy. Autorka metody wyróżnia następujące podstawowe działania terapeutyczne (Shear, 2010):

1. Psychoedukacja żałobników, mająca na celu: uzupełnienie ich wiedzy na temat doświadczenia żałoby (jako kryzysu normatywnego); omówienie występowania możliwych komplikacji podczas przeżywania śmierci bliskiego (Complicated Grief); przekazanie informacji na temat stosowanego modelu terapii żałoby (Complicated Grief Treatment).

2. Wykorzystanie metody prowadzenia dziennika samokontroli własnego doświadczenia żałoby.

3. Zaangażowanie do udziału $\mathrm{w}$ procesie terapeutycznym bliskich osób dla żałobnika.

4. Wspieranie funkcjonowania społecznego pacjenta po doświadczeniu utraty.

5. Pomoc w sformułowaniu indywidualnych celów, ukierunkowanych na przyszły rozwój osobisty klienta. 
6. Celowe przywoływanie narracji o śmierci bliskiego (opisów oraz informacji potwierdzających zgon), mające na celu przygotowanie pacjenta do akceptacji ostateczności tej utraty.

7. Konfrontowanie $z$ bodźcami, które nie są zagrażające, ale są unikane przez klienta ze względu na ich kojarzenie z doświadczeniem traumy (np. miejsca, osoby).

8. Wykorzystanie materiałów powiązanych ze zmarłym (m.in. fotografii) do zainicjowania rozmowy o utraconym bliskim. Praca ze wspomnieniami o zmarłym, ukierunkowana na urealnienie jego obrazu, zwłaszcza w przypadku występowania tłumionych, ambiwalentnych uczuć (np. gniewu lub intensywnego, nieracjonalnego poczucia winy i odpowiedzialności za tę śmierć).

9. Ćwiczenie z wykorzystaniem techniki wyimaginowanej rozmowy klienta ze zmarłym.

Analizując charakterystykę procesu terapeutycznego CGT, można dostrzec, że w tym modelu pracy połączone są strategie stosowane w ramach psychoterapii interpersonalnej (IPT) oraz techniki terapii poznawczo-behawioralnej (CBT) ukierunkowane na pracę z doświadczeniem traumy (stresem pourazowym - PTSD).

Obserwowane w modelu CGT elementy IPT to przede wszystkim działania ukierunkowane na wspieranie funkcjonowania społecznego pacjenta oraz zaangażowanie do udziału w procesie terapeutycznym osób bliskich dla żałobnika. Głównym celem terapii interpersonalnej jest poprawa relacji międzyludzkich klienta, co ma pozwolić na ograniczenie występowania u niego objawów zaburzenia. Zgodnie z podejściem IPT zaburzenie procesu żałoby traktowane jest jako konsekwencja doświadczania negatywnych emocji związanych z nieprawidłowymi relacjami z innymi ludźmi. Podczas terapii klient uczy się, jak radzić sobie $\mathrm{z}$ frustracją i napięciami pojawiającymi się w relacjach z innymi oraz jak reagować na takie emocje, jak np. żal spowodowany utratą bliskiej osoby (Shear, 2010).

Stosowane w ramach modelu CGT strategie wywodzące się z terapii poznawczo-behawioralnej (CBT) to m.in. wykorzystanie metody dziennika samokontroli własnego doświadczenia żałoby oraz ćwiczenia mające na celu konfrontowanie klienta z bodźcami, które nie są zagrażające, ale są przez niego unikane ze względu na ich kojarzenie $z$ doświadczeniem traumy (np. miejsca). Praca ze wspomnieniami o zmarłym oraz ćwiczenie z wykorzystaniem techniki wyimaginowanej rozmowy klienta z utraconym bliskim wykazują podobieństwo do metod ekspozycji na bodźce zagrażające stosowanych w terapii PTSD. Jednym z zadań tej formy konfrontowania żałobnika $z$ doświadczeniem śmierci oraz celowego przywoływania narracji o zmarłym (opisów oraz informacji potwierdzających zgon) jest przygotowanie pacjenta do akceptacji ostateczności tej utraty oraz redukcja zniekształceń emocjonalnego przetwarzania tej śmierci (m.in. intensywny lęk, poczucie winy, krzywdy, wstydu). W ramach omawianego modelu dążenie do redukcji afektywnych objawów pourazowych powiązane jest z pracą nad korygowaniem nieracjonalnych przekonań bliskich samobójców (tj. sztywnych, nieadaptacyjnych wzorców myślenia), 
co następnie ma przełożyć się na obserwowalne zmiany w ich zachowaniu (zwłaszcza ma ograniczyć ich tendencję do unikania i przeciwdziałać izolacji społecznej).

\section{ZAKOŃCZENIE}

Ze względu na opisaną w artykule tabuizację zjawiska samobójczej śmierci oraz stygmatyzację grupy pozostawionych bliskich (suicide survivors) niewielu żałobników decyduje się na podzielenie się swoim doświadczeniem utraty. Wzrastają w doświadczeniu wstydu i potępienia, które prowadzą do postępującej izolacji społecznej. $Z$ tego powodu, uwzględniając specyfikę przeżywania żałoby po samobójstwie, należy dostrzec szczególną rolę profesjonalistów, do których pozostawieni zwracają się z prośbą o pomoc. Dokonany w artykule opis charakterystyki doświadczenia żałoby po samobójczej śmierci bliskiego wskazuje na specjalne potrzeby kontaktu z tą grupą osób. W odpowiedzi na zaobserwowane zapotrzebowanie badacze poszukują najbardziej efektywnych metod pracy, wykorzystując strategie zaczerpnięte $\mathrm{z}$ różnych modeli terapeutycznych.

Spośród dostępnych propozycji pracy terapeutycznej z osobami doświadczającymi trudności w procesie przeżywania żałoby po traumatycznej śmierci bliskiego najbliższa jest mi opisana w niniejszym artykule metoda terapii Complicated Grief Treatment. Skuteczność pracy podejmowanej w ramach tego podejścia potwierdzają obiecujące wyniki badań empirycznych (Shear i in., 2001; Shear, Frank, Houck, Reynolds, 2005; Simon i in., 2008). Testując efektywność proponowanej metody terapeutycznej, Shear wykorzystała specyfikę CGT jako formy łączącej cechy terapii interpersonalnej stosowanej w leczeniu depresji oraz elementy podejścia terapii kognitywno-behawioralnej PTSD (Shear i in., 2001). Aby skontrolować wpływ terapii CGT na stan uczestników badania (osób przeżywających żałobę po traumatycznej śmierci), badaczka dokonała powtórzonego pomiaru z wykorzystaniem Skali Depresji Becka oraz narzędzia Inventory of Complicated Grief (brak polskiej adaptacji narzędzia). Pomiar dokonany po zastosowaniu manipulacji eksperymentalnej ( $\mathrm{tj}$. udziale w terapii CGT) porównany z wynikami uczestników sprzed podjęcia terapii wskazał na istotny spadek wartości wyników uzyskanych w obu narzędziach (Shear i in., 2001). Analizując skuteczność metody CGT, dokonano również porównania postrzeganej przez samych klientów efektywności działań podejmowanych w ramach tego podejścia z oceną udziału w terapii interpersonalnej (Shear i in., 2005). W tym celu uczestnicy badania (osoby spełniające kryteria CGD) zostali podzieleni na równoliczne grupy, które zdecydowały się na udział w terapii CGT lub IPT. Ocena skuteczności terapii została dokonana na podstawie analizy wyników uzyskanych za pośrednictwem (wypełnionych po zakończeniu badania) kwestionariuszy: Clinical Global Improvement oraz Inventory of Complicated Grief. Klienci zadeklarowali wyższą skuteczność terapii CGT niż terapii IPT (Shear i in., 2005). Prowadzono też 
badania, w których testowano efektywność terapii IPT oraz CGT w warunkach stosowania wspomagającego leczenia farmakologicznego (leki antydepresyjne) oraz bez stosowania tych środków (Simon i in., 2008). Uzyskane dane wskazały, że stosowanie leków antydepresyjnych istotnie wpływa na prawdopodobieństwo ukończenia terapii CGT. Aż 91\% pacjentów (spełniających kryteria CG) zażywających równolegle leki ukończyło terapię CGT, tzn. uczestniczyło w pełnym cyklu terapeutycznym, podczas gdy tylko 58\% pacjentów, którzy nie przyjmowali leków, zakończyło terapię (Simon i in., 2008). Wysoki odsetek osób kończących terapię CGT (przy równolegle prowadzonej terapii farmakologicznej) może wskazywać na szczególną adekwatność tej metody w przypadku pracy z osobami doświadczającymi trudności w przeżyciu żałoby.

$\mathrm{Na}$ podstawie przytoczonych badań porównujących metody terapii stosowane w przypadku pracy z osobami przeżywającymi żałobę po traumatycznej śmierci bliskiego można stwierdzić, że CGT wyjątkowo adekwatnie odpowiada na wskazane w niniejszym opracowaniu potrzeby tej grupy pacjentów. Uwzględniając niehomogeniczność grupy pozostawionych (m.in. zróżnicowanie ze względu na wiek, charakter więzi ze zmarłym i dominujący model reakcji na utratę), należy wskazać, że oprócz omawianej terapii CGT godny uwagi jest $\mathrm{m}$.in. model pracy z doświadczeniem traumatycznej żałoby dedykowany do pracy z dziećmi (Cohen i in., 2011). Interesującą propozycją są również próby wykorzystania muzykoterapii w procesie wspierania pozostawionych (suicide survivors) (Edmonds, 2016).

\section{BIBLIOGRAFIA}

Barrett, T.W., Scott, T.B. (1990). Suicide Bereavement and Recovery Patterns Compared with Nonsuicide Bereavement Patterns. Suicide \& Life-threatening Behavior, 20(1), 1-15.

Boelen, P.A. (2006). Cognitive-Behavioral Therapy for Complicated Grief: Theoretical Underpinnings and Case Descriptions. Journal of Loss and Trauma, 11(1), 1-30.

DOI: https://doi.org/10.1080/15325020500193655

Bonanno, G.A., Kaltman, S. (2001). The varieties of grief experience. Clinical Psychology Review, 21(5), 705-734. DOI: https://doi.org/10.1016/S0272-7358(00)00062-3

Bowlby, J. (1980). Attachment and Loss (Vol. 3: Loss, Sadness and Depression). New York: Basic Books.

Brodniak, W. (2012). Założenia ramowego programu zapobiegania samobójstwom w Polsce na lata 2012-2015. Warszawa: Instytut Psychiatrii i Neurologii.

Cohen, J.A., Mannarino, A.P., Deblinger, E. (2011). Terapia traumy i traumatycznej żałoby u dzieci i młodzieży. Kraków: Wydawnictwo UJ.

Edmonds, A. (2016). Music Therapy as Postvention for Survivors of Suicide: A Group Case Study. Arizona: Arizona State University.

Gmitrowicz, A. (2010). Postwencja - wsparcie dla osób po samobójczym zgonie kogoś bliskiego. Psychiatria po Dyplomie, 7(4), 60-62.

Gmitrowicz, A., Rosa, K. (2007). Regionalny Program Zapobiegania Samobójstwom Młodzieży. Część II: Ocena kliniczna czynników ryzyka samobójstwa młodzieży w regionie łódzkim. Suicydologia, (1), 23-28. 
Grad, O.T., Zavasnik, A. (1999). Phenomenology of bereavement process after suicide, traffic accident and terminal illness (in spouses). Archives of Suicide Research, 5(2), 157-172.

DOI: https://doi.org/10.1080/13811119908258325

Harwood, D., Hawton, K., Hope, T., Jacoby, R. (2002). The grief experiences and needs of bereaved relatives and friends of older people dying through suicide: A descriptive and case-control study. Journal of Affective Disorders, 72(2), 185-194.

DOI: https://doi.org/10.1080/13811119908258325

Hawton, K., Simkin, S. (2003). Helping people bereaved by suicide. British Medical Journal, 327(7408), 177. DOI: https://doi.org/10.1136/bmj.327.7408.177

Janoff-Bulman, R. (1992). Shattered Assumptions: Towards a New Psychology of Trauma. New York: Free Press.

Jarema, M., Rebe-Jabłońska, J. (red.). (2016). Psychiatria. Podręcznik dla studentów medycyny. Warszawa: PZWL.

Jarosz, M. (2004). Samobójstwa-ucieczka przegranych. Warszawa: Wydawnictwo Naukowe PWN.

Jordan, J.R. (2001). Is suicide bereavement different? A reassessment of the literature. Suicide \& Life-threatening Behavior, 31(1), 91-102. DOI: https://doi.org/10.1521/suli.31.1.91.21310

Kaltman, S., Bonanno, G.A. (2003). Trauma and bereavement: Examining the impact of sudden and violent deaths. Journal of Anxiety Disorder, 17(2), 131-147.

DOI: https://doi.org/10.1016/S0887-6185(02)00184-6

Kubler-Ross, E. (2002). Rozmowy o śmierci i umieraniu. Poznań: Wydawnictwo Media Rodzina.

Lukas, C., Seiden, M. (2007). Silent Grief. Living in the Wake of Suicide. New York: Jessica Kingsley Publishers.

McIntosh, J.L., Kelly, L.D. (1992). Survivors' reactions: Suicide vs. other causes. Crisis: International Journal of Crisis Intervention and Suicide Prevention, 13, 82-93.

McMenamy, J.M., Jordan, J.R., Mitchell, A.M. (2008). What do suicide survivors tell us they need? Results of a pilot study. Suicide \& Life-threatening Behavior, 38(4), 375-389.

DOI: https://doi.org/10.1521/suli.2008.38.4.375

Miller, D.T., Porter, C.A. (1983). Self blame in victims of violence. Journal of Social Issues, 39(2), 139-152. DOI: https://doi.org/10.1111/j.1540-4560.1983.tb00145.x

Mitchell, A.M., Kim, Y., Prigerson, H.G., Mortimer, M.K. (2005). Complicated grief and suicidal ideation in adult survivors of suicide. Suicide \& Life-threatening Behavior, 35(5), 498-506. DOI: https://doi.org/10.1521/suli.2005.35.5.498

Nock, M. (ed.). (2014). The Oxford Handbook of Suicide and Self-Injury. Oxford: Oxford University Press. Ostrowska, A. (1997). Śmierć w doświadczeniu jednostki i społeczeństwa. Warszawa: IFiS PAN.

Parker, H. (2014). Survivors of suicide. W: M. Nock (ed.), The Oxford Handbook of Suicide and Self-Injury (s. 479-501). Oxford: Oxford University Press.

Rando, T.A. (1985). Creating therapeutic rituals in the psychotherapy of the bereaved. Psychotherapy: Theory, Research, Practice, Training, 22(2), 236-240.

DOI: https://doi.org/10.1037/h0085500

Ringel, E. (1987). Gdy życie traci sens. Rozważania o samobójstwie. Szczecin: Wydawnictwo Glob.

Roston, D. (2017). Surviving suicide: A psychiatrist's journey. Death Studies, 41(10), 629-634. DOI: https://doi.org/10.1080/07481187.2017.1335547

Rycoft, P. (2004), Touching the Heart and Soul of Therapy. Women \& Therapy, 28(1), 83-94. DOI: https://doi.org/10.1300/J015v28n01_07

Sakinofsky, I. (2007). The aftermath of suicide: Managing survivors' bereavement. Canadian Journal of Psychiatry. Revue canadienne de psychiatrie, 52(6), 129-136.

Sanders, C.M. (2001). Powrót nadziei. Jak przeżyć stratę dziecka. Gdańsk: GWP.

Shear, K.M. (2010). Complicated grief treatment: The theory, practice and outcomes. Bereavement Care, 29(3), 10-14. DOI: https://doi.org/10.1080/02682621.2010.522373 
Shear, M.K., Frank, E., Foa, D., Cherry, Ch., Reynolds III, Ch.F., ..., Masters, S. (2001). Traumatic grief treatement: A pilot study. American Journal of Psychiatry, 158(9), 1506-1508.

DOI: https://doi.org/10.1176/appi.ajp.158.9.1506

Shear, M.K., Frank, E., Houck, P.R., Reynolds, C.F. (2005). Treatment of complicated grief: A randomized controlled trial. JAMA, 293(21), 2601-2608.

DOI: https://doi.org/10.1001/jama.293.21.2601

Simon, N.M., Shear, M.K., Fagiolini, A., Frank, E., Zalta, A., ..., Silowash, R. (2008). Impact of concurrent naturalistic pharmacotherapy on psychoterapy of complicated grief. Psychiatry Research, 159(1-2), 31-36. DOI: https://doi.org/10.1016/j.psychres.2007.05.011

Solomon, M.I. (1983). The Bereaved and the Stigma of Suicide. OMEGA - Journal of Death and Dying, 13(4), 377-387. DOI: https://doi.org/10.2190/8ATQ-A38A-5HTL-G8TT

Stroebe, W., Stroebe, M.S. (1987). Bereavement and Health: The Psychological and Physical Consequences of Partner Loss. New York: Cambridge University Press.

Sveen, C.-A., Walby, F.A. (2008). Suicide survivors' mental health and grief reactions: A systematic review of controlled studies. Suicide \& Life-threatening Behavior, 38(1), 13-29.

DOI: https://doi.org/10.1521/suli.2008.38.1.13

Thornton, G., Whittemore, K.D., Robertson, D.U. (1989). Evaluation of people bereaved by suicide. Death Studies, 13(2), 119-126. DOI: https://doi.org/10.1080/07481188908252289

WHO (2014). Preventing suicide: A global imperative. Pobrane z: www.who.int/mental_health/suicide-prevention/world_report_2014/en (dostęp: 1.09.2019).

Więdłocha, M. (2019). Żałoba po samobójstwie. W: T. Koweszko (red.), Zatrzymać samobójstwo. Poradnik dla rodzin i bliskich (s. 93-100), Warszawa: Wydawnictwo Medyk.

Zhang, B., El-Jawahri, A., Progerson, H.G. (2006). Update on bereavement research: Evidence-based guidelines for the diagnosis and treatment of complicated bereavement. Journal of Palliative Medicine, 9(5), 1188-1203. DOI: https://doi.org/10.1089/jpm.2006.9.1188

\section{SUMMARY}

The purpose of the article was to indicate the specifics of experiencing suicidal death of a loved one. The text deals with the problem of the taboo of the phenomenon of suicide and social stigmatization of suicides and their families. A meta-analysis of research reports devoted to understanding this issue was supported by the cited testimonies of people experiencing mourning after the suicide of a loved one. Differences in the experience of mourning after suicide and after death due to natural causes were considered. The subject of reflection are especially those aspects of the experience of close suicides that do not correspond to the socially approved patterns of experiencing mourning (including the lack of social approval for expressing emotions of anger and the experience of relief in the context of a loved one's death). Based on the analysis of the presented materials, potential threats were identified that may affect this group of mourners. To this end, research on the risk analysis of mental disorders among suicide survivors was discussed. In the context of the observations made in the article, the effectiveness of the therapy Complicated Grief Treatment dedicated to working with this group of clients was considered.

Keywords: suicide; mourning; suicide survivors; therapy 